\title{
Investigation on the Effects of 12 Days Intensive Competition on Some Blood Parameters of Basketball Players
}

\author{
Yildirim Gokhan Gencer ${ }^{1}$, Funda Coskun ${ }^{1}$, Mucahit Sarikaya ${ }^{1}$, Seyhmus Kaplan ${ }^{2}$ \\ ${ }^{1}$ Universty of Van Yuzuncu Yil Physical Education and Sport Department, Turkey \\ ${ }^{2}$ University of Van Yuzuncu Yil Sports Medicine Program, Turkey \\ Correspondence: Yildirim Gokhan Gencer, Universty of Van Yuzuncu Yil Physical Education and Sport Department, \\ Van, Turkey.
}

Received: February 12, 2018

doi:10.11114/jets.v6i4.3011
Accepted: February 27, $2018 \quad$ Online Published: March 7, 2018

URL: https://doi.org/10.11114/jets.v6i4.3011

\begin{abstract}
The aim of this study is to investigate the effect of intensive basketball competitions ( 10 official basketball games in 12 days intensive competition period) on blood parameters of basketball players. Blood samples were taken from the basketball players of the university team. The players were training regularly and they had no regular health problems. The average age of the players was $22,80 \pm 3,20$ years and the average height was $185,83 \pm 7,57 \mathrm{~cm}$. This study was performed on 10 volunteer basketball players. Blood samples were taken before ( 24 hours), after ( 24 hours) and during the intensive competitions. Descriptive statistics (mean and standard deviation) were applied to the data, Wilcoxon two realized sample test was used to compare the values before and after the competition period. When comparing the blood values before and after the competition period, there was significant increase in prevalence of Fe, albumin, AST, ALT, LDL, HDL, MCH, MCHC and the values of UIBC, creatinine, HCT and MPV were significantly low before the competition; $(\mathrm{P}<0.05)$.

The findings show that the physiological characteristics of basketball players are influenced by intensive competitions. In the literature, the physiological effects of regular and single-session exercises have been investigated in many studies. However, the data about the physiological effects of intensive competition periods are rather limited. A better understanding of these influences will guide the event organizers and coaches to plan the competitions and it will facilitate the preparation of the sportsmen for this intensive competition periods.
\end{abstract}

Keywords: recovery, blood parameters, physiology, basketball

\section{Introduction}

Basketball is distinguished from other branches by being a branch that has been developing continuously since the day it was first played, this change first occurred in the number of players and then in the game rules. This process is not only related to the technical and tactical features of the players, but also the number of scientific studies about physiological and motoric properties of players have increased and made contribution to the field.

The most important reason for the increase in studies on the athletes is that success is directly related to the factors that determine performance and physical and physiological characteristics (Aydas et al. 2002). Hematological and biochemical parameters may vary depending on the type, severity, duration of exercises, feeding status and the supplementation (Akmakci and Pulur 2008, Cinar et al. 2007, Cinar et al. 2010; Cinar et al. 2016; Demiriz et al. 2015; Galbo et al. 1977; Kara et al. 2010; Pancar et al. 2017). In this respect, the effect of exercises on biochemical parameters has become an area of ongoing researches. Researchers suggest that regular aerobic exercise has positive effects on fat and carbohydrate metabolism, and it causes moderate decreases in body weight, fat deposits, total cholesterol and triglyceride (Tran and Wetlmen, 1985).

The hemoglobin and hematocrit values of athletes subjected to intensive exercise program decrease characteristically and this status is regarded as sportsman anemia (Londeann, 1978). As a result of long-term workouts and competitions the energy expenditure and metabolites increase in the organism. Increased metabolites cause gradual decline in activity in the muscles and nervous system, which leads to exhaustion. Chemical, physiological, psychological and enviromental factors play an important role in this exhaustion. The metabolites accumulated blood are lactic and 
pyruvic acid as a result of carbohydrate metabolism, urea, uric acid, phosphates, creatinine and creatinin as a result of protein metabolism, acetone and ketone bodies as a result of fat metabolism. Besides, decrease in blood sugar, hypoglycemia, reduction in the amount of oxygen are the chemical factors of fatigue (Dundar, 2000).

While intensive exercise causes fatigue in the athletes, the organism recovers with adequate rest. The physical capacity of the individual increases afterwards. If the resting time after intensive exercises is insufficient for recovery, the physical capacity is deteriorated due to the prolongation of the fatigue life (Ball 1998; Bompa and Haff 2009; Halson et al. 2002; Matveyev 2004; Skurvydas et al. 1985; Wilmore and Costil 2004). In order to determine the overtraining, which is a loss of performance due to physical and mental fatigue, the hematocrit, hemoglobin, Fe, ferritin, calcium, magnesium, urea, uric acid, creatine, creatine kinase, CPK (creatine phosphokinase) and total protein should be evaluated (Gunay and Cicioglu 1998; Hackney et al. 1994; Jurgen 1994).

There are researches on the physiological effects of regular and single-session exercises in the literature. However, the number of studies examining the physiological effects of intensive competition periods is rather limited. In this context, the studies that will investigate intensive competition period will provide a better understanding of sports, sport physiology and will help to interpret the changes that occur in the body of actually healthy players (Hazar and Koc 2003). The aim of this study is to compare the changes that may occur in the blood values before and after the intensive competition period in the basketball players who played 10 official basketball matches during 12 days.

\section{Method}

The study was conducted on 10 volunteer basketball players whose average age was $22,80 \pm 3,20$ years and average height was $185,83 \pm 7,57 \mathrm{~cm}$. Players were university students without health problems and regularly trained 4 days a week. The athletes participated in the study had three group games in two separate tournaments, in which they had an average of 20-25 matches per team in the form of three groups. The first group competitions were 4 days, the second and third group competitions were 3 days lasted in 10 days. There was only 1 day resting time between the group competitions. $5 \mathrm{ml}$ blood samples were taken by venous pathway before and after competitions ( 24 hours) with potassium-edged tubes for hemogram and non-anticoagulant tubes for serum. After coagulation process the blood samples were centrifuged for 10 $\mathrm{min}$ at $1500 \mathrm{~g}$ and the serum were separated. The potassium algae samples were centrifuged for $10 \mathrm{~min}$ at $1500 \mathrm{~g}$, then the plasma samples were taken and kept at $-40^{\circ} \mathrm{C}$. CELL-DYN-3500 R brand automatic blood count device was used for analysis in the laboratory. SPSS package program was applied to data for descriptive statistics and Wilcoxon two realized sample test was used to compare the values before and after the competition.

\section{Results}

As indicated in Figure 1, there is a significant increase in prevalence of Fe, albumin, AST, ALT, LDL, HDL, MCH, $\mathrm{MCHC}$ values before and after the competition.

UIBC, creatinine, HCT and MPV values decreased significantly $(\mathrm{P}<0.05)$. The increases and decreases in other parameters were statistically insignificant $(\mathrm{P}>0.05)$. 


\begin{tabular}{|c|c|c|c|c|}
\hline \multirow[t]{2}{*}{ Variables } & \multicolumn{2}{|l|}{$\mathrm{N}=10$} & \multirow[t]{2}{*}{$\mathbf{Z}$} & \multirow[t]{2}{*}{$\mathbf{P}$} \\
\hline & Before & After & & \\
\hline $\mathbf{F e}$ & $90,9 \pm 21,04$ & $123,9 \pm 33,53$ & $-2,395$ &, $017 *$ \\
\hline UIBC & $223,5 \pm 28,21$ & $180 \pm 26,98$ & $-2,701$ &, $007 * *$ \\
\hline TIBC & $314,4 \pm 26,53$ & $307 \pm 28,92$ & $-1,276$ & ,202 \\
\hline Bun & $14,62 \pm 2,11$ & $14,53 \pm 2,75$ &,- 357 &, 721 \\
\hline Ure & $31,3 \pm 4,52$ & $30,4 \pm 6,31$ &,- 612 &, 540 \\
\hline UA & $5,73 \pm 1,42$ & $5,99 \pm 1,32$ & $-1,027$ & ,305 \\
\hline Creatinine & 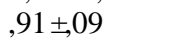 &, $85 \pm, 08$ & $-2,722$ &, $006 * *$ \\
\hline CK & $217 \pm 84,13$ & $233,6 \pm 121,75$ &,- 357 &, 721 \\
\hline Albumin & $4,33 \pm, 16$ & $4,59 \pm, 22$ & $-2,719$ &, $007 * *$ \\
\hline Total Bilirubin & $, 59 \pm 0,21$ &, $67 \pm, 21$ & $-1,070$ & ,285 \\
\hline Direct Bilirubin &, $24 \pm, 06$ &, $24 \pm, 06$ &,- 513 & 608 \\
\hline ALP & $91,4 \pm 24,21$ & $89,4 \pm 24,16$ & $-1,280$ & ,201 \\
\hline HDL & $47,77 \pm 7,86$ & $51,92 \pm 10,59$ & $-1,887$ &, $049 *$ \\
\hline LDL & $97,90 \pm 19,97$ & $117,5 \pm 25,5$ & $-2,805$ &, $005 * *$ \\
\hline Cholesterol & $172,2 \pm 28,27$ & $184,2 \pm 33,73$ & $-2,193$ &, $028 *$ \\
\hline TG & $133,2 \pm 63,14$ & $153,1 \pm 61,33$ & $-1,122$ &, 262 \\
\hline AST & $20,9 \pm 2,88$ & $36,8 \pm 16,98$ & $-2,677$ &, $007 * *$ \\
\hline ALT & $21 \pm 11,51$ & $42,2 \pm 28,22$ & $-2,803$ &, $005 * *$ \\
\hline $\mathrm{RBC}$ & $5,72 \pm 0,53$ & $5,59 \pm, 49$ & $-1,682$ & ,093 \\
\hline PDW & $13,66 \pm, 73$ & $16,97 \pm, 68$ &,- 614 &, 539 \\
\hline WBC & $7,04 \pm 1,34$ & $7,06 \pm 1,67$ &,- 102 & ,919 \\
\hline HGB & $16,05 \pm, 88$ & $15,96 \pm 1,15$ &,- 842 &, 400 \\
\hline HCT & $48,52 \pm 2,82$ & $47,72 \pm 3,12$ & $-2,405$ &, $016^{*}$ \\
\hline $\mathrm{MCV}$ & $85,24 \pm 6,62$ & $84,88 \pm 6,50$ & $-1,225$ & 221 \\
\hline МСH & $28,21 \pm 2,32$ & $28,53 \pm 2,33$ & $-2,687$ &, $007 * *$ \\
\hline МСНС & $33,06 \pm, 45$ & $33,56 \pm, 45$ & $-2,405$ &, $016 *$ \\
\hline RDW & $13,66 \pm 1,22$ & $14,31 \pm 1,67$ & $-2,203$ &, $028 *$ \\
\hline PLT & $222,5 \pm 51,02$ & $211,5 \pm 46,65$ & $-1,888$ & 059 \\
\hline MPV & $9,27 \pm 1,69$ & $8,89 \pm 1,46$ & $-2,273$ &, $023 *$ \\
\hline LY\# & $2,35 \pm, 37$ & $2,31 \pm, 30$ &,- 412 &, 681 \\
\hline MO\# & $6 \pm, 13$ &, $58 \pm, 16$ &,- 520 & ,603 \\
\hline NE\# & $3,9 \pm 1,01$ & $3,93 \pm 1,30$ &,- 308 & ,758 \\
\hline EO\# &, $14 \pm, 09$ &, $22 \pm, 20$ & $-1,604$ & ,109 \\
\hline BA\# &, $02 \pm, 04$ & $0 \pm, 0$ & $-1,414$ &, 157 \\
\hline LY\% & $34,22 \pm 4,98$ & $33,5 \pm 5,86$ &,- 968 & ,333 \\
\hline MO\% & $8,32 \pm 2,13$ & $8,49 \pm 2,24$ &,- 653 &, 514 \\
\hline $\mathrm{NE} \%$ & $54,92 \pm 6$ & $54,37 \pm 6,30$ &,- 968 & ,333 \\
\hline $\mathrm{EO} \%$ & $2,03 \pm 1,28$ & $3,05 \pm 2,31$ & $-2,103$ &, 035 \\
\hline ВА $\%$ &, $51 \pm, 14$ &, $5 \pm, 12$ &, 000 & 1,000 \\
\hline $\begin{array}{l}\text { Values are given } \\
* \text { Wilcoxon two } 1 \\
* * \text { Wilcoxon two }\end{array}$ & & & & \\
\hline
\end{tabular}

Figure 1. Blood values before and after the competition

\section{Discussion}

The findings show that the physiological characteristics of basketball players may have been affected by intensive competitions. In the literature there are studies, on the acute effects of exercise on blood parameters. Significant increases in HGB, HCT, WBC, cholesterol, HDL values and significant decreases in LDL values were found (Ibis et al. 2010; Nieman and Pedersen 1999; Novosadova, 1977; Retallick, 2007; Skurvydas et al. 1985). In some other studies , chronic effects of exercise on blood parameters were studied. It has beeen found that HDL and cholesterol levels were increased, LDL values were decreased and hematocrit and hemoglobin values were in activation (Akmakci and Pulur 2008; Apostolidis et al. 2014; Bicer et al. 2005; Nieman et al. 1993; Oztin, et al. 2003; Tran and Weltman, 1985). However, there are not enough studies about the effects of intensive competitio period on blood parameters. Cinar et al. (2013) studied on the blood parameters of soccer players during the 10-day intensive competition period and they have found a significant effect on RBC (Erythrocyte), PLT (Platelet) and HGB (Hemoglobin) values ( $p<0,05$ ) and statistically meaningless effect on WBC (Leukocyte) values ( $p>0.05$ ). In this study, fewer blood parameters were studied and blood samples were taken 2 hours after the end of the intensive competition. In our study, blood samples were taken the following day to exclude the acute effect of intensive exercise. There was a significant increase in Fe, albumin, AST, ALT, LDL, HDL, MCH, MCHC values and there was a significant decrease inUIBC, creatinine, HCT and MPV values when compared to previous values $(\mathrm{P}<0.05)$.

The increase in AST and ALT values may be result of negative effects on liver or the increase in AST along with the decrease 
in creatine may be an indirect indicator of muscle loss. Yet these results may suggest that basketball players have not rested enough to recover and have not sufficiently nourished. However, in order to make these interpretations, the athletes' nutritional and fluid consumption values should also be known. Since these values are not monitored and the number of athletes in this study is insufficient, such interpretations can not be made. Therefore, extensive studies, in which the athlete is examined and the fluid and nutritional statuses are documented, are needed. Despite the limitations of research mentioned above, there will be a better understanding of the subject with a few studies emphasizing physiological effects in intensive competition periods. Our study may make a contribution to literature by emphasizing the fact that in intensive competition periods if the players do not sufficiently rest, recover, nourish and provide liquid balance, their health may be adversely affected. In this respect, informing the organizers is essential for the health and performance of sportsmen.

\section{References}

Apostolidis, N., Bogdanis, G. C., Kostopoulos, N., \& Souglis, A. (2014). Changes in the Lipid Profile of Elite Basketball and Soccer Players After a Match, Research in Sports Medicine, 22, 100-110. https://doi.org/10.1080/15438627.2013.852095

Aydas, F., Ugras, A., \& Savas, S. (2002). Comparison Of The Selected Physical And Physiological Characteristics Of The Turkish National Boxing Team Members With Two Different Boxing Teams, Gazi Journal of Physical Education and Sports Sciences, 7(2), 11-22.

Ball, D., \& Herrington, L. (1998). Training And Overload: Adaptation And Failure In The Musculoskeletal System. Journal of Bodywork and Movement Therapies, 2(3), 161-167. https://doi.org/10.1016/S1360-8592(98)80008-9

Bicer, Y. S., Peker, I., \& Savucu, Y. (2005). Effect On Some Blood Lipits Of Organized Walking In Woman Patients That Have Heart Single Vascular Stoppage, Research of Eastern Anatolia Region, 4(1), 102-111.

Bompa, T., \& Haff, G. G. (2009). Periodization Theory and Methodology of Training, $5^{\text {th }}$ Edition, Human Kinetics

Çakmakci, E., \& Pulur, A. (2008). Effect Of National Team Camping Period Of Taekwondo Sportswomen On Some Biochemical Parameters, Selçuk University Journal of Physical Education and Sport Science, 10, 39-47.

Cinar, V., Akbulut, T., Oner, S., Pancar, Z., \& Karaman, M. K. (2016). Investigation Of Healty Life Style Behaviors Of Turkish Wrestling Federation Coaches. International Refereed Academic Journal of Sports, Health and Medical Sciences, (21), 119-136.

Cinar, V., Cengiz, S., Pala, R., \& Dundar, A. (2013). Effect of Football Practices on Certain Blood Values of Athletes, Advances in Environmental Biology, 7(5), 924-927.

Cinar, V., Mogulkoc, R., \& Baltaci, A. K. (2010). Calcium Supplementation and 4-Week Exercise on Blood Parameters of Athletes at Rest and Exhaustion, Biological Trace Element Research, 134(2), 130-135. https://doi.org/10.1007/s12011-009-8459-x

Cinar, V., Mogulkoc, R., Nizamlioglu, M., \& Baltaci, A. K. (2007). Effects of Magnesium Supplementation on Blood Parameters of Athletes at Rest and After Exercise, Biological Trace Element Research, 115(3), 205-212. https://doi.org/10.1007/BF02685995

Demiriz, M., Erdemir, I., \& Kayhan, R. F. (2015). Effects Of Anaerobic Interval Training With Different Rest Interval On Aerobic Capacity, Anaerobic Threshold And Blood Parameters. International Journal of Sports, Exercise and Training Science, 1(1).

Dundar, U. (2000). Training Theory, $5^{\text {th }}$ Edition, Bagirgan Publisher, Ankara, 115.

Galbo, H., Christensen, N. J., \& Hoist, J. J. (1977). Glucose induced decrease in glucagon and epinephrine responses to exercise in man. J. Appl. Physiol., 42, 525-530. https://doi.org/10.1152/jappl.1977.42.4.525

Gunay, M., \& Cicioglu, I. (1998). Overtraining And Athletic Performance, Gazi Journal of Physical Education and Sports Sciences, 3(1), 11-16.

Hackney, A. C, Perrmen, S. N., \& Nowackl, J. M. (1994). Physiological profiles of over trained and stale athletes: a rewiew. New studies in Athletics, 9(3), 99.

Halson, S. L., Bridge, M. W., Meeusen, R., Busschaert, B., Gleeson, M., Jones, D. A., \& Jeukendrup, A. E. (2002). Time Course Of Performance Changes And Fatigue Markers During Intensified Training In Trained Cyclists. Journal of Applied Physiology, 93(3), 947-956. https://doi.org/10.1152/japplphysiol.01164.2001

Hazar, S., \& Koc, H. (2003). The Analysis Of The Heart Structure And Heart Functions Of The Wrestler Who Were At The Turkish National Team Level By Electrocardiograph Method, Gazi Journal of Physical Education and Sports Sciences, 8,1 . 
Ibis, S., Hazar, S., \& Gokdemir, K. (2010). Acute Effect Of Hematological Parameters On Aerobic And Anaerobic Exercise, Journal of Human Sciences, 7(1).

Jurgen, S. (1994). Overtraining. New Studies in Athletics, 9(3), 93-95.

Kara, E., Gunay, M., Cicioglu, İ., Ozal, M., Kilic, M., Mogulkoc, R., \& Baltaci, A. K. (2010). Effect Of Zinc Supplementation On Antioxidant Activity In Young Wrestlers. Biological trace element research, 134(1), 55-63. https://doi.org/10.1007/s12011-009-8457-z

Lindemann, R. (1978). Low Hematocrits During Basic Training-Athletes Anemia. New England Journal of Medicine, 299(21), 1191-1192. https://doi.org/10.1056/NEJM197811232992113

Matveyev, L. P. (2004). Periodization of sports training, $1^{\text {st }}$ Editon, Ankara, Bagirgan Publisher

Nieman D. C., \& Pedersen, B. K. (1999). Exercise And Immune Function: Recent Development. Sports Medicine, 27, 73-80. https://doi.org/10.2165/00007256-199927020-00001

Nieman, D. C., Warren, B. J., O'Donnell, K. A., Dotson, R. G., Butterworth, D. E., \& Henson, D. A. (1993). Physical Activity And Serum Lipids And Lipoproteins In Elderly Women. Journal of the American Geriatrics Society, 4l(12), 1339-1344. https://doi.org/10.1111/j.1532-5415.1993.tb06485.x

Novosadova, J. (1977). The Changes In Hematocrit, Hemoglobin, Plasma Volume And Proteins During And After Different Types Of Exercise, European Journal of Applied Physiology and Occupational Physiology, 36(3), 223-230. https://doi.org/10.1007/BF00421753

Oztin, S., Erol, A. E., \& Pulur, A. (2003). The Effect Of Pliometric And Explosive Power Trainings On The Physical And Physiological Characteristics Of 15-16 Ages Group Basketball Players. Gazi Journal of Physical Education and Sports Sciences, 8(1).

Pancar, Z., Ozdal, M., \& Cinar, V. (2017). The Effect Of 4-Weekly Low Intensity Physical Activity Program In Thyroid Hormone Levels In Obese And Overweight Children, European Journal of Physical Education and Sport Science, 3(11), 1-7.

Retallick, C. J., Baker, J. S., Williams, S. R., Whitcombe, D., \& Davies, B. (2007). Plasma Volume Response To 30-S Cycle Ergometry: Influence On Lipid And Lipoprotein. Medicine \& Science in Sports \& Exercise, 39(9), 1579-1586. https://doi.org/10.1249/mss.0b013e318093f585

Skurvydas, V. S., Mickeviciene, S. K., Stanislovaitis, A., \& Mamkus, G. (1985). Effect Of Age On Metabolic Fatigue And On Indirect Symptoms Of Skeletal Muscle Damage After Stretch-Shortening Exercise. Journal of Sports Medicine and Physical Fitness; 13(3), 889-894.

Tran, Z. V., \& Weltman, A. (1985). Differential Effects Of Exercise On Serum Lipid And Lipoprotein Levels Seen With Changes In Body Weight: A Meta-Analysis. Jama, 254, 919-924. https://doi.org/10.1001/jama.1985.03360070057023

Wilmore, J. H., \& Costil, D. L. (2004). Physiology of Sport and Exercise. 3th ed., Champaign, IL: Human Kinetics.

\section{Copyrights}

Copyright for this article is retained by the author(s), with first publication rights granted to the journal.

This is an open-access article distributed under the terms and conditions of the Creative Commons Attribution license which permits unrestricted use, distribution, and reproduction in any medium, provided the original work is properly cited. 